\title{
Inoculation of Bacillus spp. and nitrogen levels increase chickpea production
}

\section{Inoculação com Bacillus spp. e doses de nitrogênio aumentam a produção de grão-de-bico}

\author{
Maria Nilfa Almeida Neta ${ }^{1}$, Elaine Soares de Almeida ${ }^{1} \odot$, Cândido Alves da Costa ${ }^{1}{ }^{\oplus}$, \\ Jéssica Aparecida dos Reis Nunes ${ }^{1} \oplus$, Luiz Arnaldo Fernandes ${ }^{1} \oplus$, Rodinei Facco Pegoraro ${ }^{1 *}([)$
}

'Universidade Federal de Minas Gerais/UFMG, Instituto de Ciências Agrárias, Montes Claros, MG, Brasil

${ }^{*}$ Corresponding author: rodinei@ufmg.br

Received in July 17, 2021 and approved in October 5, 2021

\begin{abstract}
Chickpea growth and yield are related to the balanced supply of N. In weathered soils, this factor depends on the biological activity of growth-promoting bacteria, the presence of diazotrophic bacteria, and the management of nitrogen fertilization. In this regard, this study aimed to evaluate the efficiency of inoculation with a mix of Bacillus spp. and $\mathrm{N}$ levels on chickpea cultivation. Two experiments were carried out: area 01 , characterized by shortest cultivation time and area 02 , with the longest cultivation time. For both studies, the experimental design was in randomized blocks with four replications arranged in a $2 \times 6$ factorial consisting of the absence or presence of the mix of Bacillus spp. ( $1 \times 10^{7} \mathrm{CFU}$ per $\left.\mathrm{mL}\right)$ from root isolates and six $\mathrm{N}$ levels: $0,25,50,75,100$, and 125 $\mathrm{kg} \mathrm{ha}^{-1}$. The chickpea production and yield characteristics were evaluated. In the area 01, inoculation with the mix of Bacillus spp. did not interfere with grain yield, whereas the application of lower $\mathrm{N}$ levels ( $\left.25 \mathrm{~kg} \mathrm{ha}^{-1}\right)$ increased the dry mass of branches, grains, total dry mass, and yield $\left(4.17 \mathrm{t} \mathrm{ha}^{-1}\right)$. In contrast, in the area 02 , nitrogen fertilization increased the chlorophyll index but did not interfere with the remaining production variables, whereas inoculation with Bacillus spp. increased chickpea yield by $4 \%$, resulting in a grain harvest of $4.16 \mathrm{t} \mathrm{ha}^{-1}$. Therefore, inoculation of chickpea seeds with the mix of Bacillus spp. is recommended in soils with long-time cultivation of agricultural species.
\end{abstract}

Index terms: Cicer arietinum L.; growth-promoting bacteria; agricultural yield.

\section{RESUMO}

O crescimento e a produtividade no grão-de-bico estão relacionados ao fornecimento equilibrado de N. Em solos intemperizados, esse fator é dependente da atividade biológica de bactérias promotoras de crescimento, da presença de bactérias diazotróficas e do manejo da adubação nitrogenada. Assim, objetivou-se avaliar a eficiência da inoculação com mix de Bacillus spp. e doses de N no cultivo de grão-debico. Foram realizados dois experimentos: área 01, caracterizada por menor tempo antecessor de cultivo e área 02, com maior tempo de cultivo. Para ambos os estudos, utilizou-se o delineamento experimental de blocos ao acaso, com quatro repetições, no esquema fatorial $2 \times 6$, consistindo de ausência ou presença de mix de Bacillus spp. (concentração de $1 \times 10^{7}$ UFC por mL) de isolados radiculares, e seis doses de N: 0, 25, 50, 75, 100 e 125 kg ha-1. Foram avaliadas as características de produção e produtividade do grão-de-bico. Na área 01 a inoculação com o mix de Bacillus spp. não interferiu no rendimento de grãos e a aplicação de menor dose de $\mathrm{N}\left(25 \mathrm{~kg} \mathrm{ha}^{-1}\right)$ aumentou a massa seca de ramos, grãos, total e a produtividade $\left(4,17 \mathrm{t} \mathrm{ha}^{-1}\right)$. Na área 02 a adubação nitrogenada aumentou o índice de clorofila, mas não interferiu nas demais características de produção, e a inoculação com Bacillus spp. aumentou a produtividade do grão-de-bico em 4\%, propiciando a colheita de 4,16 t ha-1 de grãos. A inoculação de sementes de grão-de-bico com mix de Bacillus spp. é indicada em solos com maior tempo de cultivo com espécies agrícolas.

Termos para indexação: Cicer arietinum L.; bactéria promotora de crescimento; rendimento agronômico.

\section{INTRODUCTION}

Chickpea is the third most cultivated legume worldwide, with 17.19 million tons produced in 2018 and a mean yield of $965 \mathrm{~kg} \mathrm{ha}^{-1}$ (Food and Agriculture Organization of the United Nations - FAO - FAOSTAT,
2020). Chickpea grains show high contents of digestible proteins (17 to $31.5 \%$ ) and essential amino acids (Jukanti et al., 2012), in addition to low sugar levels (Foster-Powell; Holt; Brand-Miller, 2002), features that increase the popularity of this crop. Furthermore, the species is adapted to semi-arid regions, associate with atmospheric $\mathrm{N}_{2}$-fixing 
bacteria, has low production costs, and high cultivation rusticity (Nascimento et al., 2016).

The Brazilian semi-arid is a favorable region for the cultivation of this legume (Artiaga et al., 2015; Nascimento et al., 2016), with yields above $2,700 \mathrm{~kg} \mathrm{ha}^{-1}$ in irrigated systems (Hoskem et al., 2017; Pegoraro et al., 2018; Almeida Neta et al., 2020; Fonseca et al., 2020). However, high chickpea yields depend on a balanced nitrogen supply $(\mathrm{N})$ and the presence of growth-promoting bacteria.

In chickpea cultivation, plant inoculation with growth-promoting bacteria such as those of the genus Bacillus favors the synthesis of phytohormones such as IAA (Mondal et al., 2019) and the secretion of exopolysaccharides, siderophores, and flavonoids, which inhibit the movement of toxic ions (Wani; Khan, 2010) and pathogenic populations (Sivaramaiah; Malak; Sindhu, 2007). These bacteria also participate in the maintenance of ionic balance in the soil solution (Hashem; Tabassum; Abd-alla, 2019), promoting phosphorus solubilization (Yadav; Verma, 2014; Hashem; Tabassum; Abd-Alla, 2019). Furthermore, they increase biological nitrogen fixation (BNF) (Sivaramaiah; Malak; Sindhu, 2007) and chickpea grain production (Wani; Khan, 2010). Therefore, inoculation with growth-promoting bacteria is recommended to improve plant development, grain production, and nutrient uptake (Yadav; Verma, 2014).

In chickpea cultivation, studies on the inoculation of Bacillus spp. under Brazilian tropical conditions as well as on plant response after mineral nitrogen $(\mathrm{N})$ application are scarce (Amaral et al., 2018; Almeida Neta et al., 2020). $\mathrm{N}$ is considered an essential nutrient for legume crops without high symbiotic efficiency. Romanyà and Casals (2019) highlight that highly fertile soils increase the BNF of chickpea, whereas no BNF increase was verified in less fertile soils.

Chickpea production also varies with the soil organic matter content (SOM). Almeida Neta et al. (2020) concluded that soils with less SOM produce $2.009 \mathrm{~kg} \mathrm{ha}^{-1}$ of grains when supplied with $125 \mathrm{~kg} \mathrm{ha}^{-1} \mathrm{~N}$, whereas soils with higher SOM showed no grain yield increase (1.780 $\mathrm{kg} \mathrm{ha}^{-1}$ ) when the $\mathrm{N}$ levels were increased.

$\mathrm{N}$ is considered an essential element for chickpea as one of the constituents of proteins, nucleic acids, and chlorophyll, among other components directly related to photosynthetic efficiency (Marschner, 2012). However, with the demand for sustainable agriculture, nitrogen fertilization should be performed consciously as wrong doses could result in losses by leaching and/or volatilization (Yadav; Verma, 2014; Joshi et al., 2019). From this perspective, sustainable cultivation with ecological agricultural practices is essential to ensure the production of healthy plants without the risk of contamination to both environment and the consumer.

Studies on the inoculation with the mix of Bacillus spp. and the management of $\mathrm{N}$ levels in soils with different use histories are scarce in Brazil. However, these studies are essential to ensure higher grain yields and sustainable cultivation. Therefore, this study aimed to evaluate the efficiency of inoculation with a mix of Bacillus spp. and $\mathrm{N}$ levels on chickpea cultivation.

\section{MATERIAL AND METHODS}

The study was conducted in the municipality of Montes Claros-MG, in two areas previously cultivated with chickpea between May and the beginning of September 2019. The first area is located at the coordinates $16^{\circ} 41^{\prime} 01.86^{\prime \prime} \mathrm{S}$ and $43^{\circ} 50^{\prime} 20.11^{\prime \prime} \mathrm{W}$. The second area is located at $16^{\circ} 40^{\prime} 57.22^{\prime \prime} \mathrm{S}$ and $43^{\circ} 50^{\prime} 20.94^{\prime \prime} \mathrm{W}$ and 626 $\mathrm{m}$. The climate of the region is classified as $A w$, with dry winters and rainy summers. Climatic conditions during the study period are shown in Figure 1.

\section{Characterization of the cultivation areas and experimental model}

The experimental design was in randomized blocks arranged in a $2 \times 6$ factorial. The first factor represented the absence or presence of the mix of Bacillus spp. at a concentration of $x 10^{7} \mathrm{CFU}$ per $\mathrm{mL}$. The second factor consisted of the $\mathrm{N}$ levels of $0,25,50,75,100$, and $125 \mathrm{~kg} \mathrm{ha}^{-1}$, supplied as urea $(45 \% \mathrm{~N})$ thirty days after emergence (DAE).

The study was conducted in two areas with different cultivation histories of agricultural species. The first (area 01) had a shorter cultivation time with annual and perennial species, lying fallow from 2009 to 2018 (predominant Guinea grass vegetation - Panicum maximum Jacq.), and chickpea cultivation in 2019 (Table 1). The second area (area 02) had a longer cultivation time with perennial and annual species (11 years). Was cultivated banana from 2009 to 2014, forage sorghum in 2015 and 2016, chickpea in 2017, lying fallow in 2018 (predominantly with Amaranthus deflexus, Amaranthus spinosus, Euphorbia heterophylla, Physalis angulata, Emilia fosbergii, Bidens subalternans, Waltheria indica, and Sorghum arundinaceum), and chickpea in 2019 (Table 1). Historically, area 2 received specific fertilization and liming for each crop in the last 11 years, according to Ribeiro, Guimarães and Alvarez (1999), while in area 01 this management was only carried out in 2019 for chickpea. 


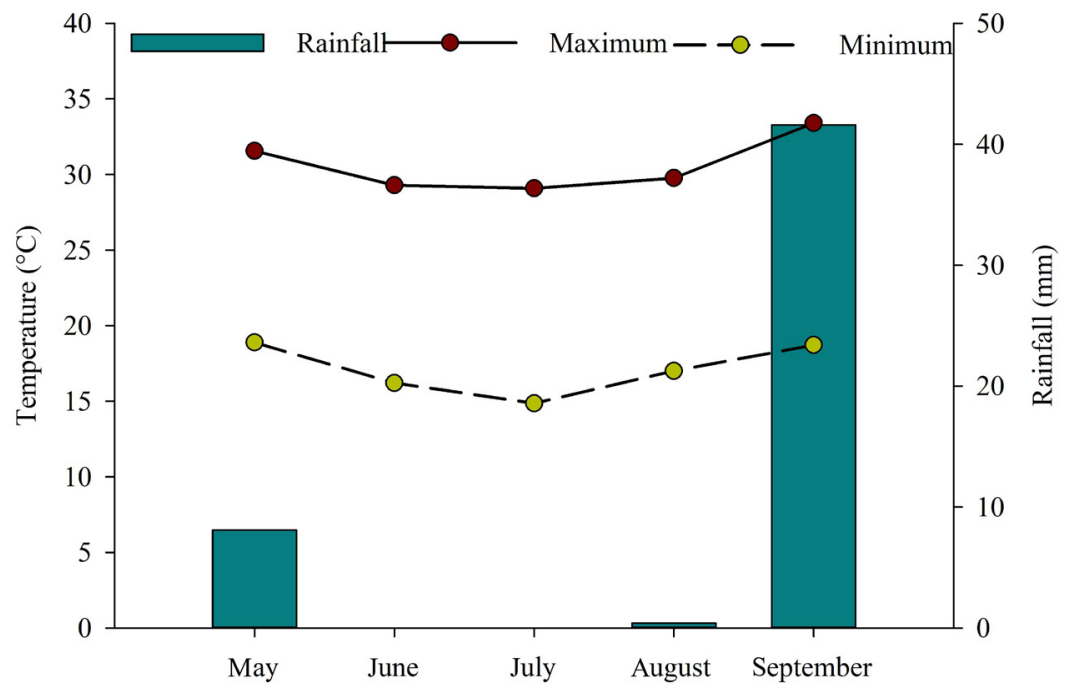

Figure 1: Maximum and minimum temperature and rainfall during chickpea cultivation in 2019, according to data from the National Institute of Meteorology- INMET (Instituto Nacional de Meteorologia - INMET, 2020).

Table 1: Representation of the cultivation history (2009 to 2019) of the areas selected for the studies with chickpea.

\begin{tabular}{|c|c|c|c|c|c|c|c|c|c|c|c|}
\hline \multirow[b]{2}{*}{ Area } & \multirow[b]{2}{*}{2009} & \multicolumn{10}{|c|}{ 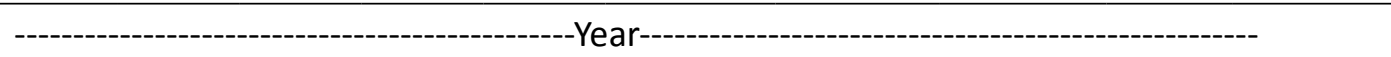 } \\
\hline & & 2010 & 2011 & 2012 & 2013 & 2014 & 2015 & 2016 & 2017 & 2018 & 2019 \\
\hline 01 & & & & & & Fallon & & & & & Chickpea \\
\hline 02 & & & Bal & ana & & & Sorghum & Sorghum & Chickpea & Fallow & Chickpea \\
\hline
\end{tabular}

The soils from the experimental areas were classified as Haplic Cambisols (Santos et al., 2018). Soil samples were collected from the $0-20 \mathrm{~cm}$ depth layer for chemical characterization twenty days before crop establishment with the aid of an auger (10 single samples per composite sample). Area 01 showed the following result: $3.60 \mathrm{dag} \mathrm{kg}^{-1}$

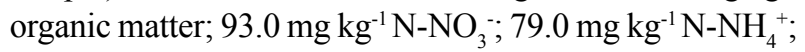
$2.58 \mathrm{~g} \mathrm{~kg}^{-1}$ total $\mathrm{N} ; \mathrm{pH}\left(\mathrm{H}_{2} \mathrm{O}\right.$ ): 5.8; $2.09 \mathrm{mg} \mathrm{dm}^{-3} \mathrm{P}$ (Mehlich 1); $81.0 \mathrm{mg} \mathrm{dm}^{-3} \mathrm{~K}$ (Mehlich 1); $8.60 \mathrm{cmol}_{\mathrm{c}} \mathrm{dm}^{-3} \mathrm{Ca} ; 1.80$ $\mathrm{cmol} \mathrm{dm}_{\mathrm{c}}^{-3} \mathrm{Mg} ; 0.00 \mathrm{cmol}_{\mathrm{c}} \mathrm{dm}^{-3} \mathrm{Al}(\mathrm{KCl}) ; 3.10 \mathrm{cmol}_{\mathrm{c}} \mathrm{dm}^{-3}$ $\mathrm{H}+\mathrm{Al} ; 10.61 \mathrm{cmol}_{\mathrm{c}} \mathrm{dm}^{-3} \mathrm{SB} ; \mathrm{t}: 10.61 \mathrm{cmol}_{\mathrm{c}} \mathrm{dm}^{-3} ; 77 \%$ base saturation; T: $13.70 \mathrm{cmol}_{\mathrm{c}} \mathrm{dm}^{-3}$. Area 02 showed the following chemical characteristics: $1.99 \mathrm{dag} \mathrm{kg}^{-1}$ organic matter; $79.8 \mathrm{mg} \mathrm{kg}^{-1} \mathrm{~N}-\mathrm{NO}_{3}^{-} ; 53.2 \mathrm{mg} \mathrm{kg}^{-1} \mathrm{~N}^{-\mathrm{NH}_{4}^{+}} ; 1.52 \mathrm{~g} \mathrm{~kg}^{-1}$ total N; $7.0 \mathrm{pH}\left(\mathrm{H}_{2} \mathrm{O}\right) ; 12.24 \mathrm{mg} \mathrm{dm}^{-3} \mathrm{P}$ (Mehlich 1); $188 \mathrm{mg}$ $\mathrm{dm}^{-3} \mathrm{~K}$ (Mehlich 1); $7.20 \mathrm{cmol}_{\mathrm{c}} \mathrm{dm}^{-3} \mathrm{Ca} ; 1.50 \mathrm{cmol}_{\mathrm{c}} \mathrm{dm}^{-3}$ $\mathrm{Mg} ; 0.00 \mathrm{cmol}_{\mathrm{c}} \mathrm{dm}^{-3} \mathrm{Al}(\mathrm{KCl}) ; 0.94 \mathrm{cmol}_{\mathrm{c}} \mathrm{dm}^{-3} \mathrm{H}+\mathrm{Al} ; 9.18$ $\mathrm{cmol}_{\mathrm{c}} \mathrm{dm}^{-3} \mathrm{SB}$; t: $9.18 \mathrm{cmol}_{\mathrm{c}} \mathrm{dm}^{-3} ; 91 \%$ base saturation; T: $10.12 \mathrm{cmol}_{\mathrm{c}} \mathrm{dm}^{-3}$.

The chickpea cultivar BRS Aleppo was used in the study, with Kabuli-type grains, semi-erect growth habit, and adaptability to the semi-arid region of the state of Minas Gerais (Nascimento et al., 2014). Sowing was performed in rows, spaced $0.50 \mathrm{~m}$, with two seeds every $0.10 \mathrm{~m}$. After emergence, the plants were thinned to 10 plants per meter, with an estimated number of 200.000 plants per hectare. The plots comprised $5 \mathrm{~m}^{2}$, with four rows of $2.5 \mathrm{~m}$.

\section{Obtainment of native bacterial isolates from chickpea roots}

The bacterial isolates were obtained from chickpea root nodules cultivated in organic management (tanned bovine manure and soil with high SOM content in a 1:1 ratio). The plants were conducted in 10-L pots, irrigated daily, and harvested at full bloom to remove the nodules. The roots were then washed and the nodules were detached and washed with autoclaved distilled water, remaining for 25 seconds in $95 \%$ ethyl alcohol and for $1 \mathrm{~min}$ in $3 \% \mathrm{NaClO}$. The plant material was then repeatedly washed five times with distilled water. After cleaning, the nodules were crushed and the suspension was diluted six times $\left(10^{-6}\right)$ in saline water. 
The suspensions were inoculated in YMA culture medium (Fred; Waksman, 1928) with $10 \mathrm{~g} \mathrm{~L}^{-1}$ mannitol, 0.5 $\mathrm{g} \mathrm{L}^{-1} \mathrm{~K}_{2} \mathrm{HPO}_{4}, 0.2 \mathrm{~g} \mathrm{~L}^{-1} \mathrm{MgSO}_{4} 7 \mathrm{H}_{2} \mathrm{O}, 0.1 \mathrm{~g} \mathrm{~L}^{-1} \mathrm{NaCl}, 0.5 \mathrm{~g}$ $\mathrm{L}^{-1}$ yeast extract, and $15 \mathrm{~g} \mathrm{~L}^{-1}$ agar, in addition to $5 \mathrm{ml} \mathrm{L}^{-1}$ bromothymol blue and $\mathrm{pH}$ adjustment to 6.8 . The isolates were incubated at $28^{\circ} \mathrm{C}$ for $48 \mathrm{~h}$ for colony counting, which were isolated and kept in TY liquid medium (Somasegaran; Hoben, 1994). After $24 \mathrm{~h}$ of incubation, the colony-forming units (CFU) were counted, followed by Gram staining of each selected and identified colony.

Bacteria were selected for proteomic analysis, and the bacterial strains were processed using identification scores above 2.0 when analyzed by matrix-assisted laser desorption/ionization time-of-flight mass spectrometry (MALDI-TOF MS) using the software MALDI-Biotyper v2.0 (Farfour et al., 2012). The species Bacillus cereus and Bacillus subtilis were identified, being described in the study as the mix of Bacillus spp. For inoculation, $1 \mathrm{~mL}$ of TY liquid medium with $1 \times 10^{7} \mathrm{CFU} \mathrm{mL} \mathrm{m}^{-1}$ was used for $100 \mathrm{~g}$ of chickpea seeds $1 \mathrm{~h}$ before planting.

\section{Crop management}

The areas selected for the experiments received soil preparation with plowing and harrowing (conventional system) fifteen days before sowing, in addition to soil correction and recommendations according to Chagas et al. (1999). Basal fertilization was performed at sowing in both areas with $110 \mathrm{~kg} \mathrm{ha}^{-1} \mathrm{P}_{2} \mathrm{O}_{5}$ (single superphosphate) and $20 \mathrm{~kg} \mathrm{ha}^{-1} \mathrm{~K}_{2} \mathrm{O}$ (potassium chloride) in the planting row, according to soil analysis. Topdressing fertilization with urea was performed close to the sowing row (approximately $5 \mathrm{~cm}$ from the plants) 30 days after emergence, followed by irrigation. At 30 and $50 \mathrm{DAE}$, the micronutrients $\mathrm{B}, \mathrm{Mo}, \mathrm{Cu}, \mathrm{Fe}$, and $\mathrm{Zn}$ were supplied by foliar application at the following rates: $0.2 \%$ boric acid $\left(0.34 \mathrm{~g} \mathrm{~L}^{-1} \mathrm{~B}\right), 0.2 \%$ sodium molybdate $\left(0.3 \mathrm{~g} \mathrm{~L}^{-1}\right.$ Mo), $0.2 \%$ copper sulfate $\left(0.26 \mathrm{~g} \mathrm{~L}^{-1} \mathrm{Cu}\right), 0.2 \%$ ferrous sulfate $\left(0.38 \mathrm{~g} \mathrm{~L}^{-1} \mathrm{Fe}\right)$, and $0.2 \%$ zinc sulfate $\left(0.40 \mathrm{~g} \mathrm{~L}^{-1}\right.$ B), respectively (Nascimento et al., 2016).

Phytosanitary treatments and irrigation were performed according to the crop requirements and the technical recommendations for the crop in the region (Nascimento et al., 2016). The weed control by hoeing was performed, with two hoeing until flowering of plants. It was not necessary to carry out disease control. There was chemical control of pests (Etiella-zinckenella e Helicoverpa armigera) with pirazol insecticide with two applications via costal pump after flowering at an interval of 20 days. The irrigation was performed by a micro-sprinkler system with a total of $400 \mathrm{~mm}$ of water applied. The initial watering shift was 2-day form seedling emergence to the beginning of flowering, after full flowering the watering shift was 4-day irrigation interval. In addition, after maturation of the pods, irrigation was cut.

\section{Characteristics evaluated}

At 60 DAE, in full bloom, total chlorophyll was determined with a chlorophyll meter (SPAD-502) by reading 20 fully developed leaflets from the upper part of the plants per plot.

At the end of the crop cycle (110 DAE), the ten central plants from each plot were collected to evaluate the following characteristics: plant height $(\mathrm{cm})$, dry plant mass (g per plant) of plants parts: leaves (MSF), branches (MSR), grains (MSG), and total mass (MST). These data were obtained after drying the plant material to constant weight in a forced-air oven at $65{ }^{\circ} \mathrm{C}$. The 100-grain mass (M100), number of pods with one grain (NV1), two grains (NV2), and total grains (NVT) were also obtained, in addition to the yield in $\mathrm{tha}^{-1}$ (PROD), with grain moisture corrected to $13 \%$. The harvest index (IC) was expressed as a percentage ((seed weight/shoot biomass) $\mathrm{x} 100$ ), and the agronomic efficiency was determined by the following equation:

$E A=\frac{\mathrm{Pta}-\mathrm{Pti}}{\mathrm{DTa}}$

Where:

$\mathrm{EA}=$ Agronomic efficiency in $\mathrm{kg}$ of grains per $\mathrm{kg}$ of nutrient applied

$\mathrm{PTa}=$ Yield of the treatment fertilized with $\mathrm{N}\left(\mathrm{kg} \mathrm{ha}^{-1}\right)$

$\mathrm{PTi}=$ Yield of the control treatment $\left(\mathrm{kg} \mathrm{ha}^{-1}\right)$

$\mathrm{DTa}=$ Fertilizer level of the treatment with $\mathrm{N}\left(\mathrm{kg} \mathrm{ha}^{-1}\right)$

\section{Statistical analyses}

Data were analyzed by analysis of variance. Subsequently, according to the significance $(p \leq 0.05)$, the t-test was used for the qualitative factor, whereas regression models were adjusted for the quantitative factor, selected based on the significance of the regression coefficients and the potential to explain the biological phenomenon. Statistical analysis was performed with the statistical software R using the package ExpDes.pt (Ferreira; Cavalcanti; Nogueira, 2013). The treatments without and with $\mathrm{N}$ application were compared by orthogonal contrasts using the statistical software Sisvar 5.3 (Ferreira, 2011). 


\section{RESULTS AND DISCUSSION}

Chickpea production in area 01 , with the shortest cultivation time (1 year of cultivation).

The interaction of the inoculation with the mix of Bacillus spp. and $\mathrm{N}$ levels was not significant $(\mathrm{p} \geq 0.05)$ for the evaluated characteristics. An isolated effect of the inoculation $(\mathrm{p}<0.05)$ with the mix of Bacillus spp. was observed on the mass of leaves, branches, total dry mass, and the number of pods with one grain, two grains, and total grains (Figure $2 \mathrm{~A}$ and $\mathrm{C}$ ). The isolated effect of the $\mathrm{N}$ levels had no influence $(p>0.05)$ on the evaluated characteristics.

The inoculation with Bacillus spp. reduced phytomass production, which decreased by 43,17 , and $22 \%$ in the leaves, branches, and total shoot part, respectively (Figure $2 \mathrm{~A}$ ). There were also fewer pods with one grain, two grains, and total grains (Figure $2 \mathrm{C}$ ). This result can be attributed to the presence of other free-living bacteria in the chickpea rhizosphere. Native free-living bacteria can perform photosynthesis and compete for soil carbon sources with the plant as well as with inoculated bacteria, as described by Elkoca, Turan, and Donmez (2010).

Negative results on chickpea biomass due to bacterial inoculation were also reported by Mnalku and Mitiku (2019), who observed lower biomass production in plants inoculated with CP-5 rhizobium strains compared to the treatments without inoculation. These results can be attributed to the inefficiency of the CP-5 rhizobium in forming symbiosis with the plant and the presence of rhizobia native to the area with chickpea planting history without inoculation.

Inoculation with the mix of Bacillus spp. did not influence $(p>0.05)$ the dry mass of grains, the 100-grain mass, and the yield (Figure 2 A. B and D). The mean yield corresponded to $3.6 \mathrm{t} \mathrm{ha}^{-1}$. The variables of plant height, total chlorophyll, harvest index, and agronomic efficiency did not differ with the presence or absence of inoculation with the mix of Bacillus spp. (Figure 2 E. F. G and H). The mean values for these variables were $84.22 \mathrm{~cm}, 40.94$, $36.05 \%$, and $5.51 \mathrm{~kg} \mathrm{~kg}^{-1}$, respectively.

The absence of effect on these characteristics due to inoculation with the mix of Bacillus spp. was attributed to the high SOM content $\left(3.60 \mathrm{dag} \mathrm{kg}^{-1}\right)$. High SOM contents may favor the diversity of nodulating and growth-promoting microorganisms in the rhizosphere of legume crops (Bidyarani et al., 2016). These microorganisms can also directly contribute to making nutrients available for the chickpea crop.

In the soil of area 01 , the higher SOM content also resulted in higher mineral $\mathrm{N}$ availability. This characteristic induces a lower chickpea propensity to form symbiosis or association with both inoculated and native rhizobacteria due to the high demand for photosynthetic energy by the plant during symbiosis (Marschner, 2012). Romanyà and Casals (2019) studied chickpea BNF in two soil types (with low and high fertility) and observed a negative correlation with the $\mathrm{N}$ from BNF in soils with high contents of organic or potentially mineralizable $\mathrm{N}$.

Inoculation with the mix of Bacillus spp. resulted in a higher dry mass proportion of branches and a lower dry mass proportion of leaves in the shoot of chickpea plants compared to the treatment without inoculation (Figure 2 A). Inoculation with the mix of Bacillus spp. could have contributed to anticipating leaf senescence at the moment of plant physiological maturity, resulting in the anticipated fall of chickpea leaves (Joshi et al., 2019).

These changes in the proportions of leaves and branches in the treatments with the presence and absence of inoculation with the mix of Bacillus spp. were not observed in the proportion of grains. Bacillus spp. probably interfered with plant physiology and may have stimulated phytohormone production, as is the case with 1-aminocyclopropane-1-carboxylate deaminase (ACC), an ethylene precursor. ACC keeps the plant in homeostasis and provides higher tolerance to stress conditions. The excretion of exopolysaccharides and siderophores also contributes to ionic balance, water uptake, and pathogen inhibition, as also observed with the action of Bacillus subtilis (Hashem; Tabassum; Abd-Alla, 2019). This growth stimulation was not observed as a result of the inoculation with the mix of Bacillus spp. However, the gain in grain production was similar to the treatment without inoculation with the bacterial mix. That is, there is no response of inoculation with the mix of Bacillus spp. on grain production in area 01 , with lower cultivation frequency with agricultural species and soils with higher SOM contents.

Nitrogen fertilization increased the dry mass of branches, grains, total dry mass, 100 -grain mass, and yield (Table 2). However, there was no statistical difference between the $\mathrm{N}$ levels, implying no increment in the characteristics and grain production with the increase in the $\mathrm{N}$ levels. Therefore, fertilization with the minimum $\mathrm{N}$ level $\left(25 \mathrm{~kg} \mathrm{ha}^{-1}\right)$ is recommended to obtain higher grain yields.

$\mathrm{N}$ application did not interfere with the dry mass of leaves, the number of pods with one grain, two grains, and total grains, plant height, total chlorophyll, agronomic efficiency, and harvest index compared to the treatment without $\mathrm{N}$ (Table 2), probably due to the high natural availability of $\mathrm{N}\left(93.0 \mathrm{mg} \mathrm{kg}{ }^{-1} \mathrm{~N}-\mathrm{NO}_{3}^{-}\right)$and SOM of $3.06 \%$. These results highlight the need to conduct other studies in soils with lower contents of SOM and 
potentially mineralizable N. Joshi et al. (2019) concluded that the combined use of $20 \mathrm{~kg} \mathrm{ha}^{-1} \mathrm{~N}$ and inoculation with Pseudomonas jeneni and Rhodococcus qingshengii (growth- promoting bacteria) resulted in the chickpea yield of 2,698 $\mathrm{kg} \mathrm{ha}^{-1}$, which is $33 \%$ above the yield obtained with the treatment without application of $\mathrm{N}$ fertilizer and inoculants.
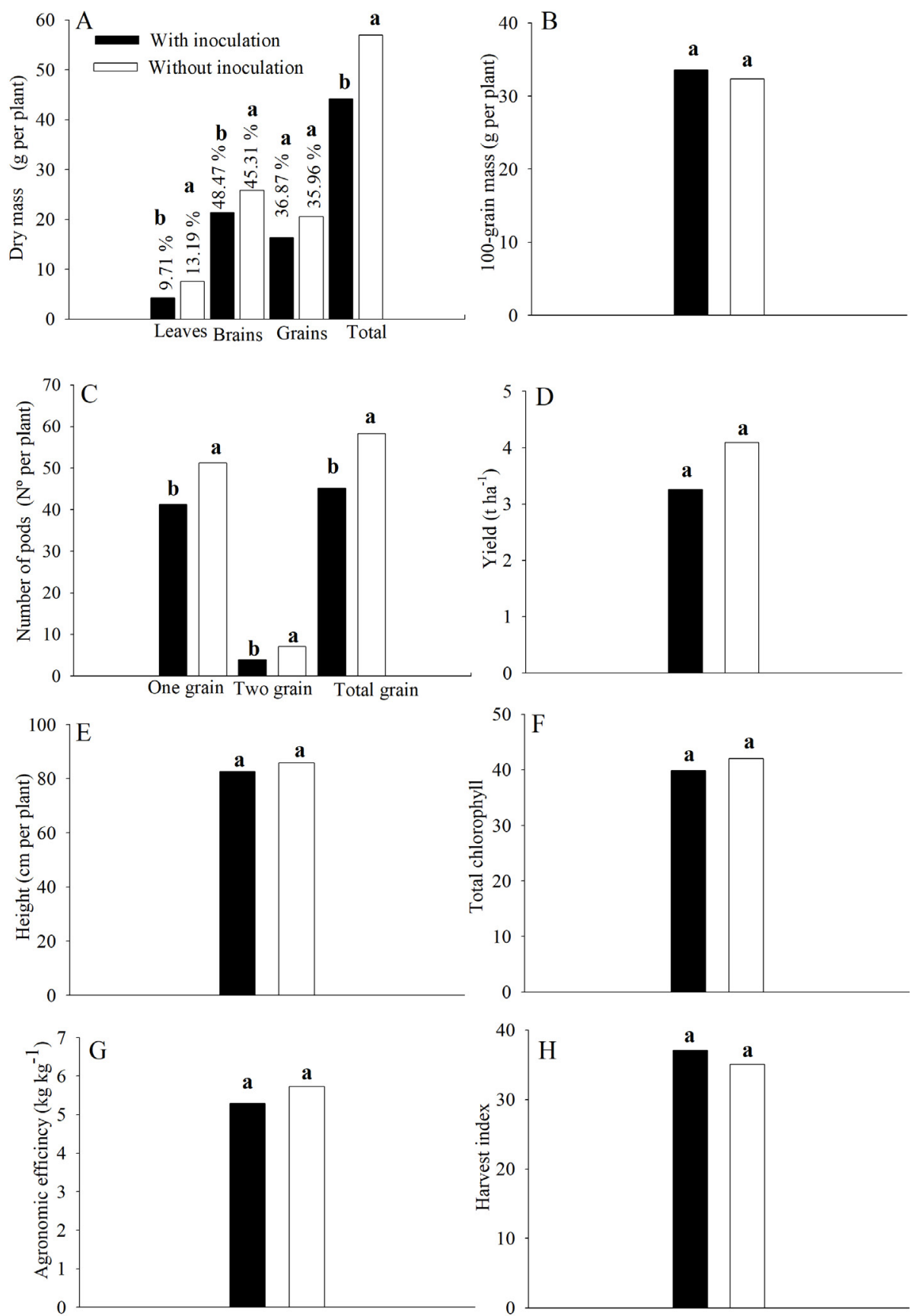

Figure 2: Effect of the inoculation with the mix of Bacillus spp. on the dry mass of leaves, branches, grains, and total mass (A), 100-grain mass (B), number of pods with one grain, two grains, and total grains (C), yield (D), plant height $(E)$, total chlorophyll (SPAD reading) $(F)$, agronomic efficiency $(G)$, and harvest index $(H)$ of the chickpea cultivar Aleppo. *Means followed by the same lowercase letter do not differ by the t-test at $5 \%$ probability. 
Table 2: Effect of fertilization with and without $N$ on the dry mass of leaves (LDM), branches (BMD), grains (GP), total dry mass (TDM), 100-grain mass (G100), yield, number of pods with one grain (NP1), two grains (NP2), and total grains (TNP), plant height $(\mathrm{H})$, total chlorophyll $(\mathrm{Cl})$, agronomic efficiency $(\mathrm{AE})$, and harvest index $(\mathrm{HI})$ of chickpea (area 01).

\begin{tabular}{cccc}
\hline Characteristics & Without N & With N & p-value \\
\hline LDM (g per plant) & 4.51 & $6.17^{\mathrm{ns}}$ & 0.15 \\
BMD (g per plant) & 17.41 & $24.83^{* *}$ & 0.01 \\
GP (g per plant) & 13.39 & $19.37^{*}$ & 0.04 \\
TDM (g per plant) & 37.44 & $53.15^{* *}$ & 0.01 \\
G100 (g) & 30.68 & $33.40^{*}$ & 0.02 \\
YIELD (t ha-1) & 2.67 & $4.17^{\text {** }}$ & 0.009 \\
NP1 (N per plant) & 37.65 & $47.91^{\mathrm{ns}}$ & 0.07 \\
NP2 (No per plant) & 3.50 & $5.94^{\mathrm{ns}}$ & 0.14 \\
TNP (No per plant) & 41.15 & $53.86^{\mathrm{ns}}$ & 0.07 \\
H (cm per plant) & 85.00 & $84.07^{\mathrm{ns}}$ & 0.86 \\
Cl & 39.25 & $41.28^{\mathrm{ns}}$ & 0.29 \\
AE (kg kg-1) & 0.00 & $6.611^{\mathrm{ns}}$ & 0.18 \\
HI (\%) & 34.69 & $36.32^{\mathrm{ns}}$ & 0.55 \\
\hline
\end{tabular}

Means followed by ${ }^{\mathrm{ns}}$ are not significant, and means followed by * and ** are significant at 5 and $1 \%$, by orthogonal contrasts (comparison between treatments without nitrogen fertilization -zero level- and treatments that received $\mathrm{N}$ levels).

The higher $\mathrm{N}$ availability for chickpea was not accompanied by higher yields. The mean yield was $3.92 \mathrm{t}$ $\mathrm{ha}^{-1}$, above the values obtained in other countries, such as India $\left(956 \mathrm{~kg} \mathrm{ha}^{-1}\right)$ and Australia $\left(928 \mathrm{~kg} \mathrm{ha}^{-1}\right)($ FAOSTAT, 2020), although the cultivation in India was performed by traditional methods and without irrigation.

In area 01 , residual $\mathrm{N}$ in the soil and the biological activity of diazotrophic bacteria supplied most of the $\mathrm{N}$ required by chickpea plants to obtain higher yields. Soils historically cultivated with chickpea and rich in SOM show high mineral $\mathrm{N}$ contents. Chickpea plants show a high deposition of leaves rich in N (Joshi et al., 2019), in addition to high natural $\mathrm{N}$ availability (Romanyà; Casals, 2019; Almeida Neta et al., 2020).

\section{Chickpea production in area 02 , with the longest cultivation time (11 years of cultivation with perennial and annual species).}

There was no effect of the interaction between the inoculation with the mix of Bacillus spp. and $\mathrm{N}$ levels on the characteristics evaluated $(\mathrm{p} \geq 0.05)$. An isolated effect of the inoculation with the mix of Bacillus spp. $(\mathrm{p}<0.05)$ was observed on the number of pods with two grains, yield, total chlorophyll, and agronomic efficiency (Figure 3). The N levels were significant for total chlorophyll ( $\mathrm{p}<0.05)$ (Figure 4).
Inoculation with the mix of Bacillus spp. increased the yield by $4 \%$, with a yield of $4.16 \mathrm{tha}^{-1}$ compared to the treatments without inoculation (3.99 $\mathrm{t} \mathrm{ha}^{-1}$ ) (Figure $\left.3 \mathrm{D}\right)$. This result highlights the high production potential and the contribution of Bacillus spp. to chickpea production in the northern region of Minas Gerais in areas with long-time cultivation. Zaheer et al. (2019) highlighted the effects of bacteria such as Bacillus spp. obtained from nodules and from the rhizosphere of chickpea plants. The authors verified an increase in phosphorus solubilization and the production of IAA, organic acids, and siderophores, which are essential for plant growth. This fact was also verified by Yadav and Verma (2014) and Mukherjee, Singh, and Verma (2020) for chickpea.

Wani and Khan (2010) reported the importance of Bacillus spp. strains in chickpea inoculation, highlighting that Bacillus spp. increased chickpea growth with the synthesis of IAA, stimulating cell elongation and division. The authors also observed that the synthesis of siderophores increased root nutrient uptake and the inhibitory effect on toxic metals, such as chromium. Mukherjee, Singh, and Verma (2020) isolated 29 bacterial strains of the genera Enterobacter sp., Bacillus sp., Pseudomonas sp., Staphylococcus sp., Pantoea sp., and 
Mixta sp. from chickpea seeds and reinoculated them in subsequent crops. The authors observed greater growth promotion in chickpea plants reinoculated with $B$. subtilis by $\mathrm{P}, \mathrm{K}$, and $\mathrm{NH}_{4}^{+}$solubilization and inhibition of Fusarium sp., suggesting the potential of its use as a bioinoculant in chickpea field cultivation.
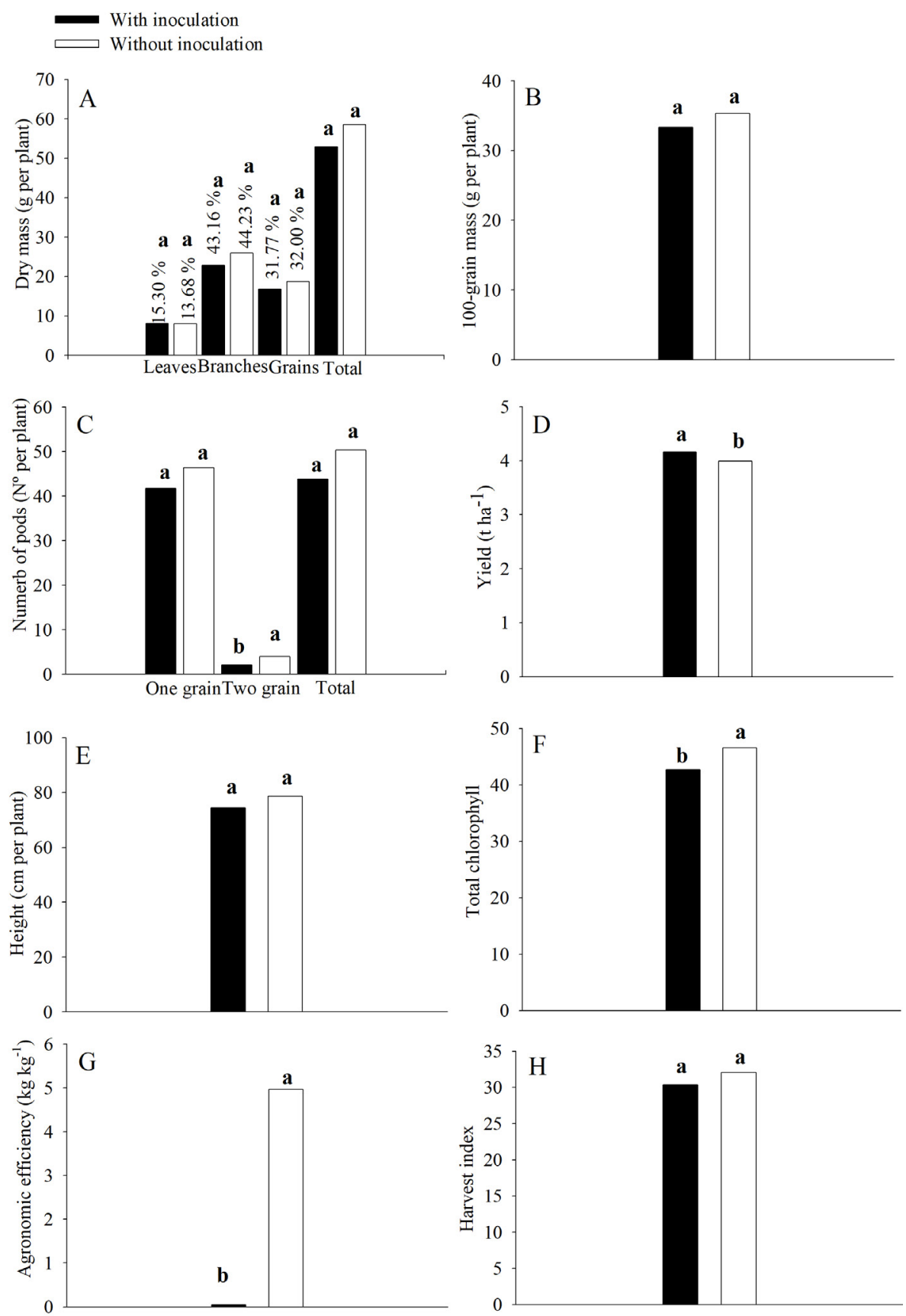

Figure 3: Effects of the inoculation with the mix of Bacillus spp. on the mass of leaves, branches, grains, and total dry mass (A), 100-grain mass (B), number of pods with one grain, two grains, and total grains (C), yield (D), plant height $(E)$, total chlorophyll $(F)$, agronomic efficiency $(G)$, and harvest index $(H)$ of the chickpea cultivar Aleppo (area 02). *Means followed by the same lowercase letter do not differ by the t-test at $5 \%$ probability. 


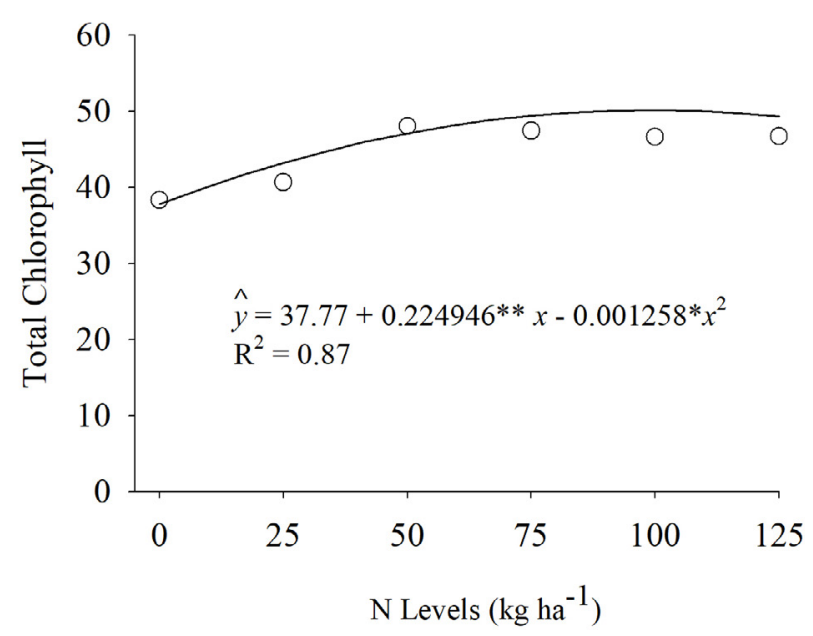

Figure 4: Effect of $\mathrm{N}$ levels on total chlorophyll of the chickpea cultivar Aleppo (area 02).

Inoculation with growth-promoting bacteria along with nodulating bacteria favor P solubilization and phytohormone production, in addition to promoting greater nodulation and BNF. Gopalakrishnan et al. (2018) observed that inoculation with Bacillus sp. and Pseudomonas sp. facilitates the obtainment of atmospheric N, ensuring high grain yields and healthy plant development. The combined use of nodulating and free-living bacteria is also recommended by Gopalakrishnan, Srinivas and Samineni (2017), Zaheer et al. (2019), and Abd-Aalla et al. (2019) to form biofertilizer for chickpea seeds.

Inoculation with the mix of Bacillus spp. reduced the number of pods with two grains (Figure $3 \mathrm{C}$ ), total chlorophyll (Figure $3 \mathrm{~F}$ ), and agronomic efficiency (Figure $3 \mathrm{G})$. However, it did not interfere with the mass of leaves, branches, grains, and total dry mass (Figure $3 \mathrm{~A}$ ), 100-grain mass (Figure $3 \mathrm{~B}$ ), the number of pods with one grain and total grains (Figure $3 \mathrm{C}$ ), plant height (Figure $3 \mathrm{E}$ ), and harvest index (Figure $3 \mathrm{H}$ ). The reduction in the number of pods with two grains and total chlorophyll with the inoculation treatment may be related to the physiological changes caused by the application of the mix of Bacillus spp. to chickpea seeds and the yield increase in this treatment. Therefore, a higher leaf $\mathrm{N}$ proportion was remobilized to grains, implying less total chlorophyll in the leaves. This occurs because the leaf $\mathrm{N}$ content directly influences leaf chlorophyll.

On the other hand, Elkoca, Turan and Donmez (2010) observed that inoculation with Rhizobium leguminosarum, B. subtilis, and B. megaterium increased the $\mathrm{N}$ content in chickpea plants and the grain protein content. This result suggests that $\mathrm{N}$ uptake increases when the association between $\mathrm{N}$-fixing bacteria and growth-promoting bacteria occurs. The authors also recommend the inoculation of chickpea seeds, especially with $B$. subtilis, to obtain higher yields in replacement to nitrogen fertilization in Turkey.

Among shoot constituents, the branches composed most of the dry matter proportion, with $44 \%$, and did not differ in the presence of inoculation with the mix of Bacillus spp. (Figure $3 \mathrm{~A}$ ). The grains remove approximately $32 \%$ of the dry mass from the area. That is, approximately 58.46 $\%$ of the chickpea shoot part remains in the soil (branches and leaves), suggesting the permanence of $6.49 \mathrm{t} \mathrm{ha}^{-1}$ of remaining dry matter, favoring subsequent crops.

Nitrogen fertilization did not influence most of the characteristics evaluated, except total chlorophyll, which was increased by $20 \%$ with this treatment (Table 3 ). The application of $89.40 \mathrm{~kg} \mathrm{ha}^{-1} \mathrm{~N}$ resulted in the maximum chlorophyll content of 57.88 (Figure 4). These results may relate nitrogen fertilization to the increase in the plant chlorophyll content without interfering with grain production.

Results suggest that the natural soil condition effectively supplied the nitrogen requirement of the plant for this production cycle.

The obtained yield of $4.08 \mathrm{tha}^{-1}$ is above the value obtained by Fonseca et al. (2020) in a study with the same chickpea cultivar $\left(3.01 \mathrm{tha}^{-1}\right)$. The authors used $100 \mathrm{~kg} \mathrm{ha}^{-1}$ $\mathrm{N}$ supplied as urea, with $45 \%$ applied at sowing and $55 \%$ as topdressing thirty days after planting. This difference in yield may be related to the planting season as the authors planted the crop at the end of summer, with harvest at the beginning of winter.

The SOM (1.99\%), mineralizable and mineral $\mathrm{N}$

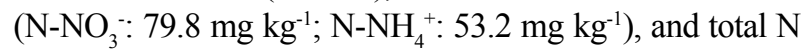
contents $\left(\mathrm{N}: 1.52 \mathrm{~g} \mathrm{~kg}^{-1}\right)$ in this area effectively supplied the chickpea nutrient requirements. This highlights the adaptive ability of this plant, especially in highly fertile soils, as suggested by Romanyà and Casals (2019). Joshi et al. (2019) suggested that the application of low $\mathrm{N}$ levels $\left(20 \mathrm{~kg} \mathrm{ha}^{-1}\right)$ along with inoculation with $P$. jeneni and $R$. qingshengii increased chickpea yield. The authors also highlight that the use of appropriate chemical fertilizer levels is beneficial to the plant and the native microbial population. In addition, the higher soil $\mathrm{pH}(7.0)$ in area 02 may have favored the activity of Bacillus spp. and other nodulating bacteria in the chickpea rhizosphere. Pandey, Gupta and Ramawat (2019) observed greater development of growth-promoting rhizobacteria (Bacillus subtilis, Bacillus pumilis Pseudomonas aeruginosa and Azotobacter chroococcum) isolated from chickpea rhizospheric soil at $\mathrm{pH} 7$ and temperature of $30^{\circ} \mathrm{C}$, contributing to the increased plant growth. 
Table 3: Effect of fertilization with and without $N$ on the dry mass of leaves (LDM), branches (BMD), grains (GP), total dry mass (TDM), 100-grain mass (G100), yield, number of pods with one grain (NP1), two grains (NP2), and total grains (TNP), plant height $(\mathrm{H})$, total chlorophyll $(\mathrm{Cl})$, agronomic efficiency $(\mathrm{AE})$, and harvest index $(\mathrm{HI})$ of the chickpea.

\begin{tabular}{|c|c|c|c|}
\hline Characteristics & Without N & $\mathrm{N}$ levels & $\mathrm{p}$-value \\
\hline LDM (g per plant) & 8.18 & $8.03^{\text {ns }}$ & 0.89 \\
\hline BMD (g per plant) & 23.48 & 24.54 ns & 0.72 \\
\hline GP (g per plant) & 17.59 & $17.81 \mathrm{~ns}$ & 0.93 \\
\hline TDM (g per plant) & 54.84 & $55.91^{\mathrm{ns}}$ & 0.87 \\
\hline G100 (g) & 34.23 & $34.34 \mathrm{~ns}$ & 0.94 \\
\hline YIELD (t ha-1) & 3.87 & $4.12^{\mathrm{ns}}$ & 0.55 \\
\hline NP1 ( $N^{\circ}$ per plant) & 42.67 & $44.36^{\mathrm{ns}}$ & 0.77 \\
\hline NP2 ( $N^{\circ}$ per plant) & 3.23 & $2.97^{\mathrm{ns}}$ & 0.76 \\
\hline TNP ( $N^{\circ}$ per plant) & 45.91 & $47.34^{\mathrm{ns}}$ & 0.82 \\
\hline $\mathrm{H}$ (cm per plant) & 77.25 & $76.47^{\mathrm{ns}}$ & 0.80 \\
\hline $\mathrm{Cl}$ & 38.31 & 45.88 * & 0.001 \\
\hline$A E\left(\mathrm{~kg} \mathrm{~kg}^{-1}\right)$ & 0.00 & $1.56^{\mathrm{ns}}$ & 0.34 \\
\hline $\mathrm{HI}(\%)$ & 31.36 & $31.18 \mathrm{~ns}$ & 0.55 \\
\hline
\end{tabular}

Means followed by ${ }^{\mathrm{ns}}$ are not significant, and means followed by * and ** are significant at 5 and $1 \%$ by orthogonal contrasts (comparison between treatments without nitrogen fertilization - zero level- and treatments that received $\mathrm{N}$ levels).

Chickpea cultivation in areas with different cultivation histories with agricultural species showed similar yields (area $01=3.92 \mathrm{t} \mathrm{ha}^{-1}$ and area $02=4.08$ $\left.\mathrm{t} \mathrm{ha}^{-1}\right)$. However, in the area with the longest cultivation time (area 02), the mix of Bacillus spp. effectively increased grain production and was not influenced by nitrogen fertilization. On the other hand, in the area with the shortest cultivation time with agricultural species (area 01), the application of $25 \mathrm{~kg} \mathrm{ha}^{-1} \mathrm{~N}$ is recommended without requiring the mix of Bacillus spp.

Different results between cultivation areas occurred due to variations in soil fertility, SOM content, $\mathrm{pH}$, and biological diversity (Almeida Neta et al., 2020). High soil fertility and $\mathrm{pH}$ favor the activity of Bacillus spp. and other nodulating bacteria in the chickpea rhizosphere of area 02 , implying a lower need for nitrogen fertilization for grain production. In area 01 , the lower inoculation response on production is related to an adverse environment to the proliferation of growth-promoting and nodulating bacteria due to the low fertility, low soil $\mathrm{pH}$, and competitiveness for soil carbon sources among native bacteria (Elkoca; Turan; Donmez, 2010).

\section{CONCLUSIONS}

Inoculation with the mix of Bacillus sp. do not change chickpea yield in the area with the shortest cultivation time with agricultural species (area 01), whereas the application of lower $\mathrm{N}$ levels $\left(25 \mathrm{~kg} \mathrm{ha}^{-1}\right)$ increased the dry mass of branches, grains, total dry mass, and yield (4.17 $\left.\mathrm{t} \mathrm{ha}^{-1}\right)$. However, in the area with the longest cultivation time (area 02), the mix of Bacillus spp. effectively increased chickpea yield by $4 \%$, resulting in a grain harvest of $4.16 \mathrm{t} \mathrm{ha}^{-1}$, and was not influenced by nitrogen fertilization. Therefore, inoculation of chickpea seeds with the mix of Bacillus spp. is recommended in soils with long-time cultivation of agricultural species.

\section{AUTHOR CONTRIBUTION}

Conceptual Idea: Pegoraro, R.F.; Almeida Neta, M.N. Literature review: Almeida Neta, M.N.; Pegoraro, R.F. Methodology design: Almeida Neta, M.N.; Pegoraro, R.F.; Costa, C.A. Laboratory analysis: Almeida Neta, M.N.; Almeida, E.S.; Nunes, J.A.R. Data interpretation: 
Almeida Neta, M.N.; Pegoraro, R.F.; Costa, C.A.; Fernandes, L.A. Writing and editing: Almeida Neta, M.N.; Pegoraro, R.F.; Costa, C.A.; Fernandes, L.A.

\section{ACKNOWLEDGMENTS}

The authors thank the Foundation for Research Support of the State of Minas Gerais (FAPEMIG), the Brazilian National Council for Scientific and Technological Development (CNPq), the Pro-Rectory Research of Universidade Federal de Minas Gerais (PRPq-UFMG), and the Brazilian Coordination for the Improvement of Higher Education Personnel (CAPES; Financial Code 001) for financial support to this research project and grating of scholarships.

\section{REFERENCES}

ABD-ALLA, M. H. et al. Mitigation of effect of salt stress on the nodulation, nitrogen fixation and growth of chickpea (Cicer arietinum L.) by triple microbial inoculation. Rhizosphere, 10:e100148, 2019.

ALMEIDA NETA, M. N. et al. Does inoculation with Rhizobium tropici and nitrogen fertilization increase chickpea production? Ciência e Agrotecnologia, 44:e016520, 2020.

AMARAL, C. L. et al. Periods of weed interference in chickpea grown under different doses of nitrogen fertilizer topdressing. Acta Scientiarum. Agronomy, 40:e35666, 2018.

CHAGAS, J. M. et al. Feijão. In: RIBEIRO, A. C. et al. (Ed.) Recomendações para o uso de corretivos e fertilizantes em Minas Gerais: $5^{a}$ aproximação. Viçosa, MG: Comissão de Fertilidade do Solo do Estado de Minas Gerais, p.306307, 1999.

ARTIAGA, O. P. et al. Avaliação de genótipos de grão de bico em cultivo de sequeiro nas condições de Cerrado. Revista Brasileira Ciências Agrárias, 10(1):102-109, 2015.

BIDYARANI, N. et al. Enhancement of plant growth and yields in chickpea (Cicer arietinum L.) through novel cyanobacterial and biofilmed inoculants. Microbiological Research, 188189:97-105, 2016.

ELKOCA, E.; TURAN, M.; DONMEZ, M. F. Effects of single, dual and triple inoculations with Bacillus subtilis, Bacillus megaterium and Rhizobium leguminosarum bv. Phaseoli on nodulation, nutrient uptake, yield and yield parameters of common bean (Phaseolus vulgaris I. cv.'elkoca-05'). Journal of Plant Nutrition, 33(14):2104-2119, 2010.
FARFOUR, E. et al. Evaluation of the andromas matrixassisted laser desorption ionization-time of flight mass spectrometry system for identification of aerobically growing gram-positive bacilli. Journal Clinical Microbiology, 50(8):2702-2707, 2012.

FERREIRA, D. F. Sisvar: a computer statistical analysis system. Ciência e Agrotecnologia, 35(6):1039-1042, 2011.

FERREIRA, E. B.; CAVALCANTI, P. P.; NOGUEIRA, D. A. E. ExpDes.pt: Experimental Designs pacakge. R package (Português). version 1.1.2. 2013. Available in: < https://sites.google.com/view/ ericbferreira/unifal/downloads-1>. Access in: June, 5, 2020.

FONSECA, J. H. S. et al. Chickpea production in response to fertilization with zinc and doses of phosphorus. Comunicata Scientiae, 11:e3106, 2020.

FOOD AND AGRICULTURE ORGANIZATION OF THE UNITED NATIONS - FAO. FAOSTAT. Food and agriculture data. 2020. Available in: <https://www.fao.org/faostat/en/\#data/QCL>. Access in: July, 24, 2020.

FOSTER-POWELL, K.; HOLT, S. H. A.; BRAND-MILLER, J. C. International table of glycemic index and glycemic load values: 2002. The American Journal of Clinical Nutrition, 76(1):5-56, 2002.

FRED, F. B.; WAKSMAN, S. A. Laboratoiy manual of general microbiology. New York, McGraw-Hill Book Company. 1928. 145p.

GOPALAKRISHNAN, S.; SRINIVAS, V.; SAMINENI, S. Nitrogen fixation, plant growth and yield enhancements by diazotrophic growth-promoting bacteria in two cultivars of chickpea (Cicer arietinum L.). Biocatalysis and Agricultural Biotechnology, 11:116-123, 2017.

GOPALAKRISHNAN, S. et al. Influence of diazotrophic bacteria on nodulation, nitrogen fixation, growth promotion and yield traits in five cultivars of chickpea. Biocatalysis and agricultural biotechnology, 15:35-42, 2018.

HASHEM, A.; TABASSUM, B.; ABD-ALLAH, E. F. Bacillus subtilis: A plant-growth promoting rhizobacterium that also impacts biotic stress. Saudi Journal of Biological Sciences, 26(6):1291-1297, 2019.

HOSKEM, B. C. S. et al. Productivity and quality of chickpea seeds in Northern Minas Gerais, Brazil. Revista Brasileira de Ciências Agrárias, 12(3):261-268, 2017.

INSTITUTO NACIONAL DE METEOROLOGIA - INMET. Dados meteorológicos de estações automáticas. 2020. Available in: <http://www.inmet.gov.br/portal/>. Access in:June,13, 2020. 
JOSHI, D. et al. Impacts of bioinoculants Pseudomonas jesenii MP1 and Rhodococcus qingshengii S10107 on chickpea (Cicer arietinum L.) yield and soil nitrogen status. Pedosphere, 29(3):388-399, 2019.

JUKANTI, A. K. et al. Nutritional quality and health benefits of chickpea (Cicer arietinum L.): A review. British Journal of Nutrition, 108(S1):11-26, 2012.

MARSCHNER, P. Marschner's mineral nutrition of higher plants. Amsterdã, Holanda. 3.ed. Academic Press. v.89. 2012. 649p.

MNALKU, A.; MITIKU, G. Response of chickpea (Cicer arietinum L.) to indigenous rhizobial isolates inoculation on vertisol of Central Ethiopian Highland. Ethiopian Journal of Agricultural Sciences, 29(2):109-117, 2019.

MONDAL, M. et al. A wastewater bacterium Bacillus sp. KUJM2 acts as an agent for remediation of potentially toxic elements and promoter of plant (Lens culinaris) growth. Chemosphere, 232:439-452, 2019.

MUKHERJEE, A.; SINGH, B.; VERMA, J. P. Harnessing chickpea (Cicer arietinum L.) seed endophytes for enhancing plant growth attributes and bio-controlling against Fusarium sp. Microbiological Research, 237:126469, 2020.

NASCIMENTO, W. M. et al. BRS Aleppo: grão-de-bico. Maior tolerância a fungos de solo. Brasília; Anápolis: Embrapa Hortaliças. Boletim Técnico, 4p. 2014.

NASCIMENTO, W. M. et al. Grão-de-bico. Hortaliças Leguminosas. Brasília, DF. Empresa Brasileira de Pesquisa Agropecuária, p. 89-118, 2016.

PANDEY, S.; GUPTA, S.; RAMAWAT, N. Unravelling the potential of microbes isolated from rhizospheric soil of chickpea (Cicer arietinum) as plant growth promoter. Biotech, 9: 277, 2019.
PEGORARO, R. F. et al. Chickpea production and soil chemical attributes after phosphorus and molybdenum fertilization. Ciência e Agrotecnologia, 42(5):474-483, 2018.

RIBEIRO, A. C.; GUIMARÃES, P. T. G.; ALVAREZ, V. H. V. Recomendações para o uso de corretivos e fertilizantes em Minas Gerais - $5^{a}$ Aproximação. Viçosa, MG: CFSEMG, 1999. 359p.

ROMANYÀ, J.; CASALS, P. Biological nitrogen fixation response to soil fertility is species-dependent in annual legumes. Journal of Soil Science and Plant Nutrition, 20: 546-556, 2019.

SANTOS, H. G. et al. Sistema brasileiro de classificação de solos. Brasília, DF: Embrapa, 2018. 355p.

SIVARAMAIAH, N.; MALIK, D. K.; SINDHU, S. S. Improvement in symbiotic efficiency of chickpea (Cicer arietinum) by coinoculation of Bacillus strains with Mesorhizobium sp. Cicer. Indian Journal of Microbiology, 47(1):51-56, 2007.

SOMASEGARAN, P.; HOBEN, H. J. Quantifying the growth of rhizobia. In: SOMASEGARAN, P.; HOBEN, H. J. Handbook for rhizobia. Springer. New York, NY. p. 47-57, 1994.

WANI, P. A.; KHAN, M. S. Bacillus species enhance growth parameters of chickpea (Cicer arietinum L.) in chromium stressed soils. Food and Chemical Toxicology, 48(11):32623267, 2010.

YADAV, J.; VERMA, J. P. Effect of seed inoculation with indigenous Rhizobium and plant growth promoting rhizobacteria on nutrients uptake and yields of chickpea (Cicer arietinum L.). European Journal of Soil Biology, 63:70-77, 2014.

ZAHEER, A. et al. Isolation, characterization and effect of phosphate-zinc-solubilizing bacterial strains on chickpea (Cicer arietinum L.) growth. Saudi Journal of Biological Sciences, 26(5):1061-1067, 2019. 